\title{
Editorial
}

This issue of Atna, the Journal of Tourism Studies marks the completion of ten successful years of the journal.The journal began its journey in the year 2006 with the objective to create a platform to publish good research based articles in the discipline of tourism, and thus promotelearning and research in tourism.It gives us immense pleasure tothank allof you, our Members of the EditorialBoard, Referees, Authors and Readers for your strong patronage to the journal.

The articles in this issue range across Tourism Education, Tourism Impacts, Consumer Behavior, Handicrafts to Yoga Tourism.A Comparative Analysis of Competency Expectations between Tourism Professionals and Tourism Academicians written by Nagarjuna G examines the gap between competency expectations of tourism academicians and tourism professionals. The author focuses on the gap existing between perception of academicians and tourism professionals on the benefits of tourism degrees and calls for urgency to frame more relevant curriculum to meet the needs of the tourism industry.

Anson KJ and Avin Thaliath in their article titled, A Study on Changes in GDP due to its Relative Dependence on Tourism Receipts explained the contribution of the tourism sector towards the GDP of the country. They also highlighted the potential of the Indian tourism sector by comparing GDP contributions from Indian tourismto Global level. Jovial Anthony Fernandes and Emy Alex in their article on Motivation for Consumer-Producer Interactions in Tourism: Disintermediation and Scope for Travel Agencies explore the changing trends in tourist buying behavior and the role of the internet and travel agents.

Robinet Jacob, Mahadevan P and Anita T Athrough their article analyses theproblems and prospects of Plant or Natural Fiber based'Green Souvenirs' of Kerala and offer suggestions for improving their market. The study considers various kinds of souvenirs made from natural fibers and analyzes the process of making the souvenirs. The authors identify and document the problems of craftsmen and artisans, and draws attention to the 
marketing challenges encountered. A study on the Impact of Yoga Tourism on Tourists Visiting Kerala authored by Ambili K examines the impact of yoga on tourists' lives and the major reasons for suitability of Kerala for practicing yoga. The article highlights the need for innovative marketing techniques to improve the supporting facilities that may increase the visits of yoga tourists to Kerala.

On behalf of the Editorial Board, I extend a sincere gratitude to the authors and reviewers for their valuable contributions to the journal. We look forward to the sustained support of academicians, researchers and professionals in our relentless effort to strengthen the discipline of tourism studies.

\section{Joby Thomas}

Executive Editor 